Gypsy Law 



\section{Gypsy Law}

Romani Legal Traditions and Culture

EDITED BY

Walter O. Weyrauch

UNIVERSITY OF GALIFORNIA PRESS

Berkeley Los Angeles London 
"Autonomous Lawmaking: The Case of the 'Gypsies' " by Walter $O$. Weyrauch and Maureen Anne Bell reprinted by permission of The Yale Law Journal Company and Fred B. Rothman \& Company from the Yale Law Journal, vol. 103 (November 1993), pp. 323-399.

Chapter I and chapters 3-II first appeared in a slightly different form in the American fournal of Comparative Law, vol. 45, no 2 (spring 1997).

University of California Press

Berkeley and Los Angeles, California

University of California Press, Ltd.

London, England

(1) 2001 by the Regents of the University of California

Library of Congress Cataloging-in-Publication Data

Gypsy law : Romani legal traditions and culture / edited by Walter $O$. Weyrauch.

p. $\mathrm{cm}$.

Includes bibliographical references and index.

ISBN 978-0-520-22186-4 (pbk. : alk. paper)

1. Law, Gypsy. 2. Gypsies-Legal status, laws, etc. I. Weyrauch, Walter O.

(Walter Otto), 1919-

Ki97.G97 2001

$346.011^{\prime} 3-\mathrm{dc} 21$

$00-46710$

Printed in the United States of America

$\begin{array}{llllllll}14 & 13 & 12 & 11 & 10 & 09 & 08 & 07\end{array}$

$\begin{array}{lllllllll}10 & 9 & 8 & 7 & 6 & 5 & 4 & 3 & 2\end{array}$

The paper used in this publication meets the minimum requirements of ANSI/NISO

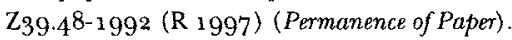

